\title{
A Fiscal Path to Sovereignty? The Basque Economic Agreement and Nationalist Politics
}

\author{
Author: Caroline Gray, University of Liverpool
}

This is an Accepted Manuscript of an article published by Taylor \& Francis in

Nationalism and Ethnic Politics on 13 March 2015, available online:

http://dx.doi.org/10.1080/13537113.2015.1003489

To cite the published article: Caroline Gray (2015) 'A Fiscal Path to Sovereignty?

The Basque Economic Agreement and Nationalist Politics', Nationalism and Ethnic

Politics, 21:1, 63-82, DOI: 10.1080/13537113.2015.1003489

\begin{abstract}
Bilateral Spanish-Basque relations over the Basque model of near fiscal autonomy (Concierto Económico or Economic Agreement) have been characterized by more tension than harmony since the 1980s. The main source of discord lies in different conceptions of the model: while the Basque nationalists seek increasing fiscal autonomy verging on sovereignty within Europe, Spanish governments see it as a form of fiscal decentralization within Spain remaining subordinate to Spanish legislation. These different conceptions cannot easily co-exist in a loose relationship of mutual tolerance because the development of the model continues to bring them into conflict, feeding into the broader political clash over how best to accommodate the Basque region within or with Spain.
\end{abstract}

\section{Author's biography}

Caroline Gray is a PhD candidate in Politics at the University of Liverpool. She holds a First Class BA and MSt in Modern Languages from the University of Oxford and reported on the politics and economy of Spain for the British Embassy in Madrid and subsequently the FT Group in 2010-2012.

\section{Acknowledgements}

This work was supported by the Economic and Social Research Council (ESRC) of the UK [ES/J500094/1]. It draws upon an extensive programme of personal interviews throughout a nine-month period of fieldwork in the Basque Country in 2014. Interviewees included current and former politicians and their advisers representing political parties across the spectrum with experience of negotiations and debates over the Basque fiscal model, legal and technical experts in the treasury departments of the Basque provinces, and academics at the University of the Basque Country specialising in the history and economics of the model. The author warmly thanks all participants for their time, interest and contribution. 
The extensive transfer of policy competences to the governments of Spain's 17 autonomous communities (ACs or regions) since the 1980s has outweighed the transfer of revenue-raising powers in all but two ACs - the Basque Country (Euskadi) and Navarre. The latter two have economic agreements with the Spanish state named the Concierto Económico and the Convenio Económico respectively (hereafter Concierto and Convenio), which grant them near fiscal autonomy. In contrast, the remaining fifteen ACs are subject to an intergovernmental revenue-sharing system called the common financing regime (régimen común de financiación), which involves a combination of revenue transfers from the central government and more limited regional taxation powers. The existence of two distinct regional financing systems and the differences in levels of regional financing and contributions to interregional solidarity that ACs experience under these have fed into growing intergovernmental conflict and competition in Spain since the turn of the century. In particular, Catalan grievances over the amount the region contributes to the rest of Spain under the common system are widely acknowledged to have contributed to the broader deterioration in Spanish-Catalan relations, especially during the financial crisis from 2008 onwards. ${ }^{1}$

The fact that the Concierto has given the Basque region greater control over its finances and has proved comparatively favourable to it in terms of resources per capita, as well as being based on strictly bilateral relations with Madrid without interregional negotiations, explains why regional financing in the Basque case has not become a visceral point of contention as in Catalonia. Yet the predominant focus in both the media and academia on the politicized debate over whether or not the Concierto is therefore a "privilege" in comparison with the common financing regime has neglected a fuller analysis of the question of why the Concierto itself still has not produced consensus between Spanish governments and the Partido Nacionalista Vasco (PNV, Basque Nationalist Party), the preeminent party in the Basque region since Spain's transition to democracy. ${ }^{2}$ Hence, the question posed here is: Why has the bilateralism that characterizes the Concierto resulted in more tension than harmony in Spanish-Basque fiscal and financial relations since the 1980s?

The bilateral nature of the Concierto has helped to mitigate the problem of inter-regional competition for resources that afflicts the common financing system and also of the perceived dominance of Madrid in wider Basque-Spanish political relations. The Concierto law and other legislation deriving from it (fundamentally the five-yearly quota laws governing the Basque contribution to the Spanish state) require mutual agreement between Basque and Spanish government delegations, both of which have equal veto power. The legislation is then always presented to the Spanish parliament as a single act, thus it can only be accepted or rejected without being subject to parliamentary debate and potential amendment. These features make the Concierto the closest current equivalent to the form of "bilateral relationship between equals" that the PNV seeks in wider Spanish-Basque political relations, under the party's latest iteration of its recurring desire to seek a new political relationship with Madrid based on a more confederal model involving "self-determination" and cosovereignty. Following the PNV's frustrated attempt under former head of the Basque government (lehendakari) Juan José Ibarretxe to turn the Basque region into a semiindependent associated state of Spain in 2001-2005, this notion of co-sovereignty has since been reconstrued under lehendakari Iñigo Urkullu to envisage an extension of the "pacted" nature of the economic Concierto to wider political relations, with explicit calls for a "political Concierto". ${ }^{3}$ 
Nevertheless, the bilateral nature of the Concierto frequently fails to work smoothly in practice, resulting in more discord than agreement. Since the first Conciertos were agreed with the Basque provinces of Araba/Álava, Bizkaia and Gipuzkoa back in 1878, the model has proved surprisingly adaptable to the times, and never more so than in the almost 35 years since the first Concierto of the democratic period was approved in 1981. And yet this has also led to strikingly different perspectives on what the model can and should be, even within the self-proclaimedly pro-Concierto camp: where some continue to see a taxation model subject to and adapted to Spanish legislation, others now envisage more fully-fledged fiscal sovereignty, in which the Basque provinces would be sovereign in fiscal matters within Europe to more or less the same degree as the Spanish state, rather than being subordinate to it. ${ }^{4}$ From the turn of the century in particular, there emerged a growing rift in perspectives as to how the Concierto should be developed in a changing regulatory context with the addition of the supranational European sphere, which had not featured when the Concierto of 1981 was negotiated. Discrepancies in the views of successive Spanish and Basque governments have fed into the broader clash in views over the degree of autonomy that Euskadi should be afforded within the Spanish state. A certain irony thus emerges whereby the PNV is touting the bilateral nature of the Concierto as an exemplary basis for a new Basque-Spanish political relationship and yet disagreements over the Concierto's development also contribute to the wider dissatisfaction fuelling this very search for new pro-sovereignty political formulas outlined in the introduction to this collection.

Some clarification of terms is required here, since the definitions of and distinction between fiscal autonomy and fiscal sovereignty are not clear-cut. In brief, fiscal autonomy when applied to subcentral governments usually describes a large degree of freedom in raising and spending taxes but still within the boundaries of some rules set by the wider state, as is currently true of Euskadi. Fiscal sovereignty, meanwhile, is more often applied to states themselves and suggests complete autonomy in setting fiscal policies without any outside interference. In practice, complete fiscal sovereignty has now become almost obsolete in Europe since individual member states are subject to some wider European fiscal legislation. Here, however, fiscal sovereignty when applied to the Basque provinces describes the aspiration to reach the same level of sovereignty in setting tax structures and policies in most respects as held by Spain itself. Representatives of the Basque institutions refer to the provinces as fiscally sovereign already in the case of taxes for which they have been granted full regulatory autonomy.

This study starts with an account of the main features of the Concierto and the origins of the discrepancy in conceptions over the model. It then examines three of the main longstanding areas of Basque-Spanish contention over the Concierto: the debate over the Basque contribution to inter-regional solidarity; disputes over BasqueSpanish corporation tax differences; and differing views on how to update the Concierto within the regulatory context of the European Union. This is followed by an analysis of whether the bilateral nature of the Concierto has helped to resolve the discrepancies in these fundamental areas of contention, investigating the impact of the main factors on the bilateral relationship, namely political alliances, party ideology, inter-regional competition and the state of the economy. Finally, the concluding section considers the implications of the growing difficulty in reconciling different conceptions of the Concierto for the future of Spanish-Basque fiscal and financial relations. 


\section{The Basque fiscal model: workings, origins and conceptions}

Under the Concierto, the Basque provinces (also known as "historical territories" and "foral territories") are responsible both for collecting almost all taxes and for regulating the majority of them. The Basque government uses these tax revenues to cover the costs of the policy competences it has assumed (which include the most fundamental areas of public services such as health and education) and also to pay an annual quota (cupo) to the Spanish government towards the few nonassumed competences for which the Spanish state remains responsible (e.g. foreign and defence policy). The quota covers $6.24 \%$ of the share of the Spanish state budget for these general expenses covered by tax revenues, broadly in line with the region's share of Spain's GDP. The Basque AC comprises three provinces (Araba/Álava, Bizkaia and Gipuzkoa), which each have their own treasury. A relatively small share of the total tax revenues they raise is used to pay the quota, which in recent years has accounted for around $8 \%-15 \%$ of the Basque annual budget. The remaining revenues go towards the common resources of the Basque region, approximately $70 \%$ of which are passed upwards to the regional government to cover its competences, while the rest are split between the diputaciones (provincial governments) and the local or municipal authorities. The internal organization of the region is thus essentially confederal in nature. ${ }^{5}$

Following the transition to democracy, this system of near fiscal autonomy in the Basque Country and also Navarre became known as the régimen foral or foral/charter regime (from fuero or medieval charter), in contrast to the régimen común which was developed for the other autonomous communities. Under its First Additional Disposition, the Spanish Constitution of 1978 pledged to respect the historical rights of the "foral territories", which was fundamentally taken as a reference to the historical tradition of the Basque and Navarran provinces in raising their own taxes. In the Basque case, the Basque and Spanish authorities reached an agreement in 1980 (approved by law in 1981) to restore the Concierto to the provinces of Bizkaia and Gipuzkoa (after General Franco had abolished it there in 1937) and update it for Araba/Álava (which, along with Navarre, had retained its Concierto by supporting the Francoist side). While the three Basque provinces retained their responsibility for tax collection, for the first time they would combine to pay one single Basque quota to Madrid following the creation of the autonomous community.

The Concierto of 1981 marked a significant departure from its predecessors, most notably in the design of the quota, the size of which had previously been based on what the Spanish treasury believed it would hypothetically raise in tax revenues were it collecting in the provinces. This was because Spain had originally conceded to the arrangement in 1878 primarily for practical reasons since the central treasury did not immediately have the technical means or capacity to collect taxes in the Basque provinces after the abolition of their fueros or legal charters in 1876 following the Basque defeat in the Third Carlist War. The arrangement was also fundamentally designed to appease the Basque liberal oligarchy of the time by allowing them to secure beneficial tax deals with the central government. A vestige of the "fueros" in economic terms thus remained while any political dimension in the form of selfgovernment had been abolished. The agreement was originally intended to be a temporary one for a transitional period of eight years until the Basque provinces became fully integrated into the Spanish tax system, but instead ended up staying in force thereafter. ${ }^{6}$ 
The Basque Concierto of 1981, which was set to expire on 31 December 2001, was updated in 2002 with a new permanent agreement. Every time Spain introduces a new tax or modifies an existing one, this calls for bilateral negotiations to be held with a Basque delegation to agree if and how to delegate the relevant tax-raising power, deciding whether the Basque provincial treasuries will have the authority to regulate the tax or only to collect it. ${ }^{7}$ Under the current legislation, they collect almost all taxes and have almost full regulatory autonomy to design the main direct taxes (income, wealth, corporation, inheritance and non-resident taxes) and the minor indirect taxes (capital transfer tax and stamp duty, and gaming duties). They only lack regulatory autonomy in the main indirect taxes (VAT and excises), which account for around $90 \%$ of total indirect tax revenues and are determined by the Spanish state, within the narrow parameters set by EU legislation. Within their regulatory capacity, the Basque provinces are still subject to some general harmonization rules within the Spanish state, as follows: they must adhere to the international agreements signed by Spain; they must not distort competition among firms or free movement among Spanish regions; and fiscal pressure (tax to GDP ratio) in the provinces should be "equivalent" to that in the rest of Spain. The latter two of these principles are, however, inherently ambiguous and open to different interpretations.

The Concierto receives cross-party support from the two main statewide parties, the Partido Popular (PP, Popular Party) and the Partido Socialista Obrero Español (PSOE, Spanish Socialist Workers' Party), as well as the PNV. In the case of the statewide parties, however, their respective Basque federations almost always support measures pertaining to the Concierto in the Basque parliament that are at times then rejected by their colleagues in Madrid due to wider implications for other regions in Spain, which can cause internal party contradictions. This also gives the PNV the opportunity to present itself as the only true defender of the Concierto and, in the view of the Basque PP, to appropriate it as a nationalist instrument of fiscal sovereignty. ${ }^{8}$ This goes to the heart of the fundamental debate between the Basque PP and the PNV over the Concierto, both of which consider themselves the party the most supportive of the model but conceive of it differently. While the Basque PP sees it as a decentralized fiscal model subject to the Spanish tax system and legislation, the PNV has come to envisage it as an instrument of fiscal sovereignty in its own right.

The roots of the current day discrepancy date back to the afore-mentioned origins of the Concierto itself. While the Basque PP takes the starting point of the Concierto as the agreements of 1878 with the Basque provinces spearheaded by their predecessors among the liberal elites and in Álava in particular (a historical stronghold of the Spanish right), the Basque nationalists look further back, remembering the Conciertos as the last vestige of what had originally been a wider set of political rights based on mutual equality governing the relationship between Spain (or previously Castile) and the Basque provinces. In opposition to the PNV's conception of the Concierto as an instrument of fiscal sovereignty for the Basque region as a whole (albeit respecting the role of the provinces as home to the treasuries), the Basque PP also issues a reminder that the three Basque provinces have only shared a Concierto agreement since 1981, which in itself was aided by the fact that the Concierto had never been abolished in Álava. Even among the parties who consider themselves supporters of the Concierto, conceptions of the model and its ultimate aim and purpose thus differ. The Concierto of 1981 in effect combined preand post-1878 conceptions, for example the requirement for "pacted" bilateral agreement was based more on the original fueros than the first Conciertos. 


\section{The solidarity debate}

The Concierto has been subject to a growing number of attacks from both PP and socialist politicians in other ACs and from the most centralist party Unión Progreso y Democracia (UPyD, Union Progress and Democracy) founded in 2007 the only statewide party actively to oppose the Concierto even in the Basque Country. ${ }^{9}$ This is primarily on account of the fact that the Basques do not contribute to the equalization mechanism for financing public services included in the common regime, which is seen to reduce their contribution to inter-regional redistribution. The resources the Basque AC receives are based on its regional fiscal capacity since, broadly speaking, it keeps all its tax revenues except for those used to pay the quota to the central government, which only uses a very small share of Basque tax revenues. Since the Basque Country and Navarre are relatively rich regions whose GDP per capita is among the highest in Spain, a system in which their resources are based on their own fiscal capacity rather than estimated needs (as in the common regime) gives them greater resources. This contributes to a level of per capita financing at least $50 \%-60 \%$ higher than the average of the other fifteen regions. ${ }^{10}$

The quota does include a contribution to the Inter-Territorial Compensation Fund, which is designed ultimately to achieve inter-regional income redistribution by promoting development in less prosperous regions and was originally envisaged during the transition to democracy as the main means of inter-regional solidarity. However, this Fund is small since its purpose was later taken over in part by EU structural and cohesion funds and it also ended up acquiring a much more secondary role in terms of inter-regional redistribution in Spain compared to the financial flows involved in the equalization mechanism for financing public services in the common regime. ${ }^{11}$

The quota, although it only accounts for a small proportion of Basque tax revenues, is also usually interpreted as fulfilling a redistributive purpose since the Basque contribution towards non-assumed competences is broadly in line with its share of Spain's GDP (6\%-7\%) rather than population (4\%-5\%). Basque politicians often point out as much whenever the Concierto comes under political attack. ${ }^{12}$ Nevertheless, the $6.24 \%$ figure agreed in 1981 was not explicitly designed to incorporate a solidarity component. ${ }^{13}$ Indeed, under the "quota system" (sistema de сирo), the PNV has consistently maintained since the 1980s that the $6.24 \%$ should apply to financial flows in both directions - not only to the Basque contribution to the competences fulfilled by the Spanish state, but also to the Basque share of any funds from the Spanish state to fulfil specific competences (often deducted from the quota) - thus confirming that it does not strictly envisage the $6.24 \%$ as a solidarity contribution.

There is however a significant other side to the coin which the Basque parties supportive of the Concierto seek to emphasize. Most notably, the unilateral risk which the fiscal model involves for the Basque region and the lack of any guaranteed minimum revenue from the central government encourages accountability and responsibility. The size of the quota does not depend on what the Basque provincial treasuries collect but rather on the size of the Spanish state budget for non-assumed competences, which encourages efficiency since the Basque region loses out if its own tax collection increases more slowly (or decreases more quickly) than that of the Spanish state. This contrasts with the convoluted revenue-sharing arrangements under the common regime, in which the regions have greater spending than revenue-raising competences $-\mathrm{a}$ form of fiscal decentralization which creates an accountability gap 
and encourages substate governments to seek further funds from the central government to cover over-spending. ${ }^{14}$

Indeed, the level of responsibility the Concierto thus entails combined with the potentially onerous and unpopular nature of tax collection contributed to deterring any other region including Catalonia from seeking a similar model during the Transition. ${ }^{15}$ Calls for a fiscal pact for Catalonia only started to surface later, from the late 1990s onwards, but even then Catalan politicians would consistently seek a bilateral deal of their own rather than an exact replica of the Concierto in part since they have opposed the form of unilateral risk the latter entails and wished instead to ensure a guaranteed minimum level of funding - especially since Catalonia accounts for a much larger share of Spain's GDP (18-20\%).

In the context of the recent financial crisis, clashes between these interpretations of the Concierto and the resources it provides reached new heights. The Basque region weathered the crisis far better than most other regions in Spain due to a number of factors, not least since it had prioritised developing an industry-based economy centred on exports in recent decades and avoided the domestic-focused construction boom that prevailed elsewhere in Spain before collapsing. The accountability the model fosters also discouraged overspending in the boom years, unlike in many regions under the common regime where spending increased, current income was insufficient to cover current expenditure, and the regional authorities would look to the central government for extra funds and the regional savings banks (cajas de ahorros) for loans to cover the gap - until the crisis hit, the central government was no longer so forthcoming with funds, and most of the savings banks collapsed. While the central government had to set up various mechanisms from 2012 onwards to lend money under strict budgetary compliance conditions to numerous cash-strapped regions under the common regime unable to cover their needs or access any other financing sources, the Basque region remained self-sufficient. ${ }^{16}$ There is little common ground between those who attribute this relatively healthier financial position fundamentally to better economic decisions and financial management by the Basque institutions under the Concierto in comparison with the behaviour of the common regime ACs, and those who suggest the Basques unfairly receive surplus financing through the Concierto in comparison to other comparable regions under the common regime. Accusations of surplus financing not only relate to the lack of contribution to the equalization mechanism for financing services discussed here, but also to other features such as the valuation of non-assumed competences and the VAT adjustment rate, both of which are interpreted by critics as overly favourable to the Basque region. ${ }^{17}$

\section{Corporation tax: interpreting harmonization}

Interpretation of the harmonization criteria has created another substantial area of controversy in Basque-Spanish fiscal relations, particularly in relation to the Basque use of corporation tax. Conflicts over harmonization between Spain and the Basque region increased drastically as the Concierto was developed and Basque fiscal competences grew. The series of tax incentives, deductions and exemptions - which became known as "tax holidays" - for newly established firms that the Basque provinces introduced in the 1990s to encourage startups and investment, combined with the tendency to introduce a lower corporation tax rate than that of the Spanish state, led to an unprecedented number of legal challenges arguing that the ambiguous "principle of no distortion" was being infringed to create unfair competition. Such 
challenges came not only from the Spanish state itself but also from the governments of the surrounding Spanish regions as well as trade unions and business associations based in them. The conflicts also went beyond the internal sphere of the Spanish state to reach the EU institutions. ${ }^{18}$ The fundamental issue at stake throughout has been the fine line between uniformization and harmonization, with the Spanish institutions interpreting the latter more restrictively than their Basque counterparts.

The fact that the fiscal policies of the Basque provincial treasuries became subject to far greater legal challenges within Spain than those presented against the fiscal policies of the neighbouring uniprovincial Navarre region with its Convenio (or indeed any other AC under the common regime) was in part due to their different regulatory status. Under the Spanish Constitution, provincial assemblies can only pass regulations (reglamentos), which can be challenged in the administrative courts by any number of agents whose interests the regulation affects. In contrast, the Spanish and regional parliaments pass laws (leyes) that can only be challenged in Spain's Constitutional Court by a very limited number of institutions and officials listed in Article 162 of the Constitution. As a result, corporation tax deductions and incentives passed by the Basque Juntas Generales (Basque provincial parliaments) became subject to continuous litigation from neighbouring regions (especially La Rioja) and business associations and trade unions within them, in addition to the Spanish state. The PNV-led Basque government therefore presented a draft bill to the Spanish parliament, following unanimous cross-party approval in the Basque parliament in June 2007, aiming to secure legal status and protection for the tax and fiscal rules adopted by the Basque Juntas Generales. This is what became known - rather unfortunately - as the Ley de Blindaje ("Shield Law"). ${ }^{19}$ Both the PP and the PSOE in Madrid opposed PNV approaches on the subject from 2005 onwards due to the implications for other regions in Spain, despite the full support of their respective Basque delegations for such a measure, until the law was finally approved under the PSOE government in 2010.

While the Ley de Blindaje would prevent agents at regional level in Spain from continuing to challenge Basque fiscal measures, the full scope of the problem over corporation tax cuts and incentives was nevertheless much wider, encompassing conflicts with the Spanish state and indeed the European Union. From the Basque government perspective, Spanish state challenges against Basque fiscal policies have in large part been politically motivated, exacerbated by the fact that the final arbitrers in many cases, Spain's Supreme and Constitutional Courts, are known for their political bias towards the Spanish government. On the other hand, critics argue that the Basque institutions have exacerbated tensions by almost always waiting until the Spanish government approves a fiscal reform for Spain and then introducing its own with comparatively lower corporation tax rates (the latest Basque fiscal reform in 2013 which preceded its Spanish counterpart in 2014 was the first notable exception). Political opponents of the PNV and some independent economists have also suggested that the nationalists were too aggressive with their "tax holiday" legislation in the 1990s or at least made a fundamental error in failing to notify the European Commission appropriately, in what some interpret as a misjudged bid to assert political and fiscal autonomy from Spain. ${ }^{20}$ The European Commission later ruled in 2001 that the main tax incentives the Basque provincial treasuries had introduced in the 1990s were unlawful state aids, ordering Spain to recover the aids from the beneficiaries.

Gaining appropriate recognition of the Basque taxation powers at European level has been fraught with difficulties given the unique nature of such a developed 
model of fiscal autonomy within a wider member state. When the Supreme Court of Justice of the Basque Country presented the case of the Basque provinces to the Luxembourg Court in 1997, seeking clarification as to whether the tax incentives they had introduced in 1993 were compatible with the Treaty of European Union, lawyer General Saggio's conclusion that such measures could be considered a territorially selective state aid since they only applied to one region (the Basque Country) within a wider state (Spain) threatened the capacity of the Basque provinces to set any corporation tax rates or incentives even minimally different from those of the Spanish state. The situation changed, however, with the Azores tax ruling of 2006. This had clear implications for the Basque region, supporting the Basque right to set different corporation tax rates from the Spanish treasury within certain parameters, due to the region's compliance with the requirements of procedural, institutional and economic autonomy. The EU rulings against the Basque tax holidays of the 1990s still stood nevertheless since the incentives were deemed incompatible with fair competition in the common market.

The Azores ruling and the Ley de Blindaje have helped to reduce the culture of litigation over Basque corporation tax measures (often refered to as the "judicialization" of the Concierto) and given these a stronger legal standing within both Spain and Europe, but from the PNV's perspective they alone are insufficient. Discrepancies in the interpretation of harmonization between the Spanish state and the Basque provinces persist, as do perceptions of a biased Spanish legal system. There remains a clash in perspectives between those who advocate that the Basque provinces should have the same capacity over corporation tax as each individual EU member state, and those in favour of greater harmonization with Spanish legislation.

\section{The Concierto in the EU}

Looking ahead, the PNV-led Basque government and technical experts within the provincial treasury departments seek to develop the fiscal autonomy model to take full account of the European and wider international context. One of the main aspirations since the turn of the century has been to gain representation within the Spanish delegation in European and international fora on fiscal affairs. During the 2001 negotiations for a new Concierto agreement, this became the main source of conflict with the Spanish PP government. The Basque delegation proposed the Basque institutions should participate in Spain's preparatory meetings for the Economic and Financial Affairs Council (ECOFIN) and the Spanish delegation to the ECOFIN working groups and meetings. The Spanish negotiating team, however, wanted instead to include the Basque participation within the general framework for the participation of the ACs in EU matters, through the Sectoral Conference designated for that purpose (established in Law 2/1997 of 13 March), which gives the ACs a weaker legal status and no direct representation in Europe. Ultimately it was the Basque side that had to back down temporarily to enable the new Concierto to be approved belatedly in May 2002 under Law 12/2002. The issue of representation in international fora remained pending and would not start to be achieved until almost nine years later on the back of a political pact with the PSOE. From 2011, Basque provincial treasury representatives would start to participate alongside their Spanish state counterparts in three key ECOFIN working groups addressing fiscal questions relevant to the competences afforded to the Basque provinces by the Concierto.

From the PNV's perspective, the obstacles both PP and PSOE central governments erected to the Basque participation in ECOFIN were more political than 
technical in nature, forming part of the Spanish state's broader reluctance to give the ACs a voice and legal standing within the European sphere. Technical experts working in the Basque provincial treasuries argue that participation in such fora is appropriate and even imperative since Basque fiscal competences are directly affected by European legislation, and suggest Spain should look to other federal and decentralized countries in Europe (e.g. Germany, Belgium and Austria) which have taken steps to regulate the participation of their regions or federal provinces in such spheres where relevant to their competences. ${ }^{21}$

Beyond strictly technical fora such as the ECOFIN working groups, the PNV ultimately aspires to secure the right to Basque representation within the Spanish delegation in the ECOFIN meetings themselves, which are more political in nature (making any agreement with the Spanish state in this regard even less likely). It also seeks representation in other international fora on fiscal matters such as the Organization for Economic Cooperation and Development (OECD). There is no common ground between this outlook and that of the main statewide parties, which do not consider the need for Basque representation in ECOFIN and other international fora an unequivocal given. Even the Basque federation of the PP does not consider Basque representation in ECOFIN necessary since the Basque provincial treasuries are subject to wider Spanish fiscal legislation. ${ }^{22}$

Aside from the question of representation in fiscal matters in Europe, the PNV also aspires to be less subject to Spanish legislation in areas of tax structure and regulation where the Basque institutions remain subordinate to the Spanish treasury. ${ }^{23}$ Some suggest the Basques should have the right to design their own tax system and structure, in contrast to the current system whereby the Basque provinces are subject to the Spanish tax system and structure: everytime Spain creates or modifies a tax, it must then negotiate the degree of autonomy the Basques will have in collecting and regulating the tax in their territories. Similarly, although indirect taxes - most notably VAT - are to a large degree harmonized throughout Europe, as long as member states retain some small margin for manoeuvre there are calls for the Basque provincial treasuries to be able to vary their VAT rates in direct response to European legislation rather than being subject to the additional intermediary of Spanish legislation. Again, such proposals fit with the viewpoint that suggests the Concierto should be developed to give the Basques the same fiscal competences as Spain itself, in stark contrast to the perspective of the Spanish statewide parties which see the Concierto strictly as a form of fiscal decentralization within Spain. Indeed, the Basque nationalists suggest developing a model of fiscal harmonization between the Basque Country and Spain under which both have equal levels of fiscal competence could serve as a model for fiscal harmonization at EU level between member states. ${ }^{24}$

\section{Have bilateral relations helped to resolve differences?}

The VAT negotiations in 1985 were one of the first acid tests of the Concierto's adaptability to a changing regulatory context through bilateral negotiations: the Spanish treasury was initially opposed to the Basque request to transfer the responsibility for VAT collection to the Basque provinces citing technical difficulties, but came to accept the Basque proposal including their suggested adjustment rate. ${ }^{25}$ From then onwards, VAT (and later excises too) in the Basque region would be collected by the Basque provincial treasuries and then undergo an adjustment to compensate for the difference between how much they actually collect 
and how much they are owed, since VAT is a tax on individual consumption but collected through a tax on corporate production.

Nevertheless, such instances where substantial differences of opinion over how to develop the Concierto have been resolved using technical arguments first and foremost, without one side simply ceding ground to the other in light of other contextual or political factors, have been very rare in the decades since the Concierto of 1981 was approved. Such agreements have only tended to be reached on relatively minor issues or on the reduced number of more substantial issues where both sides have held a very similar position from the outset of negotiations, as in the case of the decision taken by the PP-led absolute majority Spanish government and the PNV-led Basque government to make the Concierto a permanent rather than time-limited agreement for the first time under the 2002 law. In almost all the major questions, strong differences between the Basque and Spanish delegations in terms of their conceptualization of the Concierto have made it impossible to find a common middle ground and thus prevented agreements until if and when other contextual factors (usually political support or alliance arrangements) have led one side to accept the other's proposal as part of a pact. This section analyses the fundamental impact of various factors on the ability or not of the Basque and Spanish delegations to resolve disagreements relating to the main areas of contention introduced previously.

\section{Political pacts and alliances}

Either formal coalition or more usually informal support arrangements between statewide parties and the PNV have proved the primary facilitator of agreements over the Concierto since the 1980s, enabling the Basque nationalists to develop the model as desired in return for supporting other statewide party policies or goals. The role of mutual bargaining and support arrangements between Spanish governments and regionally-based parties is well documented ${ }^{26}$ but less so in relation specifically to the development of the Concierto. In particular, major agreements were reached with the PSOE majority Spanish government in 1987 as part of a deal to enable the Partido Socialista de Euskadi (PSE, Basque federation of the PSOE) to form a Basque coalition government with the PNV, and subsequently under the PP minority Spanish government of 1996-2000 and the PSOE minority Spanish governments of 2004-2008 and 2008-2011, when the statewide parties needed the PNV's support in the Spanish parliament.

After the Concierto had been approved in 1981, significant Basque-Spanish differences over its development set in almost immediately. The Concierto legislation had set a provisional quota for the first year of its application (1981) but stipulated that a five-yearly quota law should be agreed thereafter to prescribe the methodology for calculating the quota. A draft law for the first five-year period (1982-1986) was meant to be presented by July 1981, but no agreement was reached then or in the following years due to Spanish-Basque discrepancies over both the imputation index (6.24\%) and the valuation of the competences the region was due to assume (such as health and social services), among other issues. By late 1986, none of the provisional quotas from 1981 onwards had been reconciled, the quota law still had not been approved, and the transfer of competences was frozen due primarily to financing disputes. And yet all of these issues would be resolved in 1987 when the PSE formed a coalition government with the PNV and the socialist government in Madrid conceded to the PNV's wishes in return, fundamentally accepting the valuations and methods of calculation proposed by the nationalists. The deal was a political one 
struck directly with prime minister Felipe González, effectively bypassing his treasury minister Carlos Solchaga. By compromising on the Concierto and the quota, the socialists could ensure the stability of the PSE-PNV Basque coalition, bring the PNV into the fold of Spanish state governance and emphasize their achievement of a Basque-Spanish understanding that had not been possible under a one-party PNV government. ${ }^{27}$

Following the years of socialist government in Madrid, the PNV made rapid progress in developing the Concierto once the PP had won power for the first time in 1996 but without an absolute majority. Under an agreement in May 1997, the authority to collect special taxes and non-resident taxes was assigned to the Basque provinces for the first time and they were also granted significant regulatory autonomy over some other taxes - most notably personal income tax (Impuesto sobre la Renta de las Personas Físicas, IRPF) - which they had previously only collected. ${ }^{28}$ These developments formed a crucial part of the package of measures that the PNV agreed with the PP, in return for which the PNV supported the investiture of José María Aznar and promised to provide legislative support for his minority government in the Spanish parliament thereafter.

Once the PP had won an absolute majority for the first time in 2000, however, the tables turned. During the 2001 negotiations for a new Concierto agreement, it was the Basque side - now lacking in bargaining power - that failed to secure its proposal that the Basque institutions should participate in ECOFIN working groups and meetings. The beginnings of such participation would not finally be agreed until 2010, when the minority socialist government of José Luis Rodríguez Zapatero needed the PNV to support its 2011 budget and in return allowed the Basque provincial treasury representatives to start to participate alongside their Spanish state counterparts in the relevant ECOFIN working groups. Similarly, it was only when the minority PSOE government needed PNV support for its 2010 budget that it finally changed its stance and supported the afore-mentioned Ley de Blindaje in return, which was then swiftly pushed through and passed on 19 February 2010.

Nevertheless, such pacts have not always been followed through in their entirety. When the 2007-2011 quota law was designed, a dispute emerged as to how much the Basque government should receive of the funding provided by the Spanish government to ACs under the common financing system for (1) extraordinary financing (i.e. beyond the original budget allocation) for the health system; (2) extraordinary financing to develop the Education Law (in this case, in relation to children aged under three); and (3) a new dependency law. The debate was further complicated by opposition from some sectors, most notably the PP (even including its Basque federation), to giving the Basques any share of the extraordinary financing for competences already transferred since they usually pay for such competences with their own taxes. Echoing the debates in the 1980s over the valuation of the Basque share of health and social services, the PSOE government argued the Basque region should receive an amount of funding in proportion to its population size rather than the $6.24 \%$ share (matching the imputation index in the quota) proposed by the Basque delegation, but the nationalists won the argument since the PSOE needed their support. ${ }^{29}$ The PSOE nevertheless backtracked on the $6.24 \%$ agreement almost immediately, and debate on this subject dragged on thereafter, continuing under the subsequent majority PP government that came into power in 2011.

At the time of writing, none of the quotas since 2007 have been settled due to continuing Basque-Spanish government discrepancies over this and several other unresolved issues and no agreement has been reached on a new quota law for the 
period from 2012 onwards (the 2007-2011 one has simply been rolled over). The occurence of two absolute majority PP governments since 2000 has clearly reduced the PNV's bargaining power, but the failure to resolve differences over the 2007-2011 quota law under the PSOE-led minority government before the PP returned to power in 2011 would suggest that resolving differences over the Concierto is not always feasible even under minority Spanish governments seeking PNV support in parliament. Beyond the question of parliamentary alliances, agreeing the development of the Concierto has arguably become more problematic in recent years than in previous decades due to the emergence of other exacerbating factors, which the following section addresses.

\section{Party ideology, inter-regional competition and economic crisis}

The PNV and Basque technical experts involved in Concierto-related negotiations observe essentially the same levels of opposition from both PP- and PSOE-led Spanish governments towards proposals to update the Concierto to give the Basques growing fiscal autonomy and sovereignty within Europe, unless the PNV has political bargaining power. ${ }^{30}$ From this perspective, both statewide parties are accused of sharing the same politically centralist ideology regarding the role of the Spanish state in international affairs. In terms of economic ideology, however, differences between the PSOE and PP have historically impacted the development of the Concierto. The afore-mentioned agreement in 1997 to give the Basques a significant degree of regulatory autonomy over IRPF was not only for politically expedient reasons but also reflected the PP's support at the time for the hypothesis that fiscal corresponsibility encourages fiscal discipline. Under the previous socialist government, a white paper on fiscal corresponsibility had been commissed and presented by a technical delegation in 1995, in response to calls from some regions (most fundamentally Catalonia) with a view to reforming the common financing regime. In response, the new PP government proposed to start by sharing IRPF with the regions first. In 1996 it granted some regulatory autonomy over IRPF to the ACs under a reform of the common financing regime, while the agreement with the Basques over the Concierto followed in 1997. Only the PSOE genuinely did not agree with the move and attempted to block it, arguing that different income tax rates in different regions of Spain threatened equality and efficiency. ${ }^{31}$

Nevertheless, the PP has since taken a u-turn to become more centralist in economic affairs (as well as other policy areas such as education), advocating recentralization as a form of rationalization, in particular in response to the poor fiscal discipline of many regions under the common financing regime that became apparent during the financial crisis and given the need to comply with EU budgetary targets. Comparisons between the decisions taken by the PNV and the PP before and after the turn of the century reveal how both have increasingly moved towards opposite ends of the centralist-autonomist spectrum in their attitudes towards fiscal matters, which in turn reduces the possibilities for agreement over the Concierto's development. While the PNV originally only sought the ability to collect rather than regulate the main indirect taxes (as seen in the VAT negotiations of the 1980s), it now aspires to the greatest regulatory autonomy possible in both direct and indirect taxes. Meanwhile, the PP has moved from advocating the sharing of taxation powers with the regions back in the 1990s to looking to recentralize fiscal control in some respects, for example by proposing to take away the power of regional governments to create their 
own taxes (a power already limited in practice by legal challenges presented by the Spanish state towards any such taxes created).

This ideological shift on the part of the PP has coincided with the growing criticism from other ACs in Spain and also more recently from UPyD towards the Concierto. Although the Concierto is bilateral in nature, it is far from immune to wider inter-regional pressures and tensions. For most of the 1980s and 1990s the Concierto was the subject of relatively little attention and even less envy from other regions given the level of responsibility that tax collection entails, which helped to create the conditions for purely Basque-Spanish bilateral agreements. But this situation would start to change around the turn of the century as reports on the fiscal balances of the regions with the Spanish state emerged suggesting many regions under the common regime were getting a poor deal and as Catalonia began to raise demands for a bilateral financing arrangement. During the economic boom years when the central government had sufficient funds to do so, it could partly keep tensions at bay by reforming the common financing regime in ways which consistently promised to increase each region's resources beyond the status quo, but the last such reform in 2009 proved immediately insufficient as the financial crisis fully set in. The severe strain the common financing regime came under only served to increase long-standing criticism from other regions towards the "exceptionalism" of the Basque and Navarran economic agreements.

This climate has compounded the reluctance of Spanish governments regardless of their political colour to develop the Concierto any further and to allow for any change that might result in a reduction of the quota. For example, a major source of discrepancy which has contributed to the longstanding stalemate at the time of writing over the settlement of quotas since 2007 and the lack of a new quota law for the period 2012-2016 concerns Basque calls to revise the methodology to calculate the rate to update the quota (índice de actualización). Each five-yearly quota law establishes a base year quota and a rate to update it thereafter based on the increase (or decrease) in the state collection of taxes covered by the Concierto agreement elsewhere in Spain. The 2007-2011 quota law stipulated that the rate would be subject to revision following the reform of the common financing regime in 2009 since this could affect it, but the Spanish government has so far not heeded Basque requests for negotiation in this regard.

\section{Conclusion}

The bilateral relationship governing Spanish-Basque fiscal relations has come under increasing strain. During much of the 1980s and 1990s the Concierto was developed extensively and disagreements with Spanish governments over the model's evolution and annual quota payments tended eventually to be resolved in a way which aligned with the PNV's proposals, but the political and regulatory environment subsequently evolved. Since the turn of the century, the behaviour of both the conservative and socialist statewide parties has clearly suggested they consider the development of the Concierto to have gone far enough, in contrast to the PNV which sees the growth and consolidation of the EU regulatory context as a prime opportunity to develop the Concierto further as a tool of fiscal sovereignty within Europe. Political pacts and alliance arrangements between the PNV and the Spanish statewide parties became the main facilitator of agreements over the Concierto from the 1980s onwards but they have become increasingly difficult to secure in the face of other exacerbating factors such as the PP's ideological shift towards recentralization, inter-regional 
competition for resources and the economic crisis. The mere fact of a bilateral relationship, while understandably preferable from the Basque perspective to the alternative of a relationship determined unilaterally by Madrid or subject to interregional agreement, has not in itself been able to reconcile increasingly different conceptions of the Concierto - a problem exacerbated by the absence of any consensus over the wider question of the degree of autonomy or even sovereignty to afford the Basque region in a political sense. These different conceptions cannot easily co-exist in a loose relationship of mutual tolerance between Spanish and Basque governments. The development of the Concierto necessarily involves phases of renegotiation or changes de facto as a result of extraneous developments, which will inevitably continue to bring different conceptions of it into conflict. 


\section{NOTES}

${ }^{1}$ See C.M.Gray, "Smoke and mirrors: How regional finances complicate SpanishCatalan relations”, International Journal of Iberian Studies 27, no. 1 (2014): 21-42.

2 The PNV has won every Basque regional government election with a minority since the first in 1980, only once being forced into opposition in 2009-2012 due to coalition politics.

3 "El PNV pide extender el sistema bilateral del concierto a todo el autogobierno vasco”, Deia, 10 July 2014.

${ }^{4}$ Observation based on information garnered in an extensive interview programme in the Basque Country in 2014. See acknowledgements.

${ }^{5}$ For further explanation of the Concierto in English, see Ignacio Zubiri, The Economic Agreement between the Basque Country and Spain (Bilbao: Asociación para la Promoción y Difusión del Concierto Económico “Ad Concordiam”, 2010), http://www.conciertoeconomico.org/phocadownload/libros/economic agreement.pdf (accessed 14 November 2014) and "An Assessment of the Economic Agreement: Myths and Realities,” in Joseba Agirreazkuenaga and Eduardo Alonso Olea, eds., The Basque Fiscal System. History, Current Status, and Future Perspectives (Reno: Center for Basque Studies, University of Nevada, 2014), 125-172.

${ }^{6}$ On the historical origins of the Concierto, see Eduardo Alonso Olea, El Concierto Económico (1878-1937). Orígenes y formación de un Derecho Histórico (Oñati: Instituto Vasco de Administración Pública, 1995).

${ }^{7}$ Delegating tax-raising power is used here as an approximate translation of "concertar el impuesto", the official Spanish terminology in this context.

${ }^{8}$ Impressions of the Basque PP perspective are informed by personal interviews with Antón Damborenea, head of the Basque PP in Bizkaia, 9 July 2014; and Aitor Uribesalgo, PP treasury minister of the provincial government of Araba/Álava, 10 October 2014.

${ }^{9}$ Mikel Buesa, Economics professor at the Complutense University of Madrid and founding member of UPyD in 2007-2009, coined the term "el pufo vasco" "“the Basque swindle") in a study by the same name he published in 2007 criticizing the methodology used to calculate the Basque contribution to the Spanish state via the quota.

${ }^{10}$ Zubiri, The Economic Agreement, 112; Angel de la Fuente, "Sobre el Pacto Fiscal y el Sistema de Concierto” (March 2012): 4-5, https://www.fundacionsepi.es/ciea/Pacto\%20Fiscal\%20(Angel\%20de\%20la\%20Fuent e).pdf (accessed 14 November 2014).

${ }^{11}$ Gray, "Smoke and mirrors": 23.

${ }^{12}$ See, for example, the interview with lehendakari Iñigo Urkullu in El País, 2 October 2014.

${ }^{13}$ Personal interviews with Pedro Azpiazu, PNV parliamentary spokesperson for the Economy, 15 September 2014; and with technical experts in the Bizkaian treasury department, 4 April and 8 October 2014.

${ }^{14}$ On this theory, see Jonathan Rodden, Hamilton's Paradox: The Promise and Peril of Fiscal Federalism (New York, Cambridge University Press, 2006).

${ }^{15}$ Personal interviews with present and former Basque politicians involved in negotiations with their Catalan counterparts at the time; Eduardo J. Alonso-Olea, "La autonomía y su financiación. Debates parliamentarios, 1977-2012” in Diana Repeto 
García, coord., Las Cortes de Cádiz y la Historia Parliamentaria (Cádiz: Universidad de Cádiz, 2012), 877-879.

${ }^{16}$ Gray, "Smoke and mirrors": 36-37.

${ }^{17}$ Angel de la Fuente, “¿Está bien calculado el cupo?”, Moneda y Crédito 231: 93-

150. Preliminary draft online: http://pareto.uab.es/wp/2010/80310.pdf (accessed 14 November 2014).

${ }^{18}$ On the questions raised during the 1990s about the Concierto's fit within the EU context, see Ignacio Zubiri, El sistema de Concierto Económico en el Contexto de la Unión Europea (Bilbao: Círculo de Empresarios Vascos, 2000).

${ }^{19}$ Gonzalo Martínez Etxeberria, "La Ley Orgánica 1/2010, de 19 de febrero, sobre el mal llamado 'blindaje’ del Concierto Económico vasco”, Gaceta tributaria del País Vasco (Zergak), no. 47 (2014): 209-218, http://www.conciertoeconomico.org/joomdocs/autores/ZERGAK-2014_MARTINEZG_La-LO-1-2010_sobre-el-mal-llamado-blindaje.pdf (accessed 14 November 2014). ${ }^{20}$ See also the interview with Ignacio Zubiri in Forum Fiscal: la revista tributaria de Álava, Bizkaia y Gipuzkoa, no. 199 (June 2014): 89.

${ }^{21}$ See Gemma Martínez Bárbara, Armonización Fiscal y Poder Tributario Foral en la Comunidad Autónoma del País Vasco (Bilbao: Instituto Vasco de Administración Pública, 2014), 93-108.

${ }^{22}$ See note 8.

${ }^{23}$ See note 13.

${ }^{24}$ Personal interview with former lehendakari Juan José Ibarretxe, 28 October 2014.

${ }^{25}$ Personal interview with Pedro Larrea, former Basque government deputy treasury minister in the mid 1980s, 20 June 2014.

${ }^{26}$ See Bonnie Field, this collection.

${ }^{27}$ Impressions based on personal interviews with former lehendakari José Antonio Ardanza (PNV), 28 April 2014; Gonzalo Múgica (PSE), legal adviser to former deputy lehendakari Ramón Jáuregui, 18 July 2014; and Carlos Aguirre (PSE), then Economic Planning Director of the Basque government, 13 October 2014. On the technical specifics of the dispute, see José Luis Larrea Jiménez de Vicuña, "Las leyes quinquenales de cupo: un acuerdo para el futuro", Revista Vasca de Administración Pública, 23 (1989), http://www.conciertoeconomico.org/joomdocs/RVAP 1989_LARREA_J_Las_leyes quinquenales_de_cupo.pdf (accessed 14 November 2014).

${ }^{28}$ Aside from increasing Basque fiscal powers, delegation of the authority to collect the special taxes would stop the quota from becoming negative. Over the years, the transfer of resource-intensive competences to the Basque region combined with strong revenue collection by the Spanish state (especially the special taxes) had resulted in a rapid reduction in the size of the quota.

${ }^{29}$ For the agreement reached, see Informe Anual Integrado de la Hacienda Vasca 2011 , http://www.ogasun.ejgv.euskadi.net/contenidos/informe_estudio/iai/es_iai_2011/adju ntos/2011\%20IAI.pdf (accessed 14 November 2014), 204-205.

${ }^{30}$ Personal interviews with Basque politicians and technical experts that have been involved in negotiations with their Spanish counterparts.

${ }^{31}$ For example, El País, 20 March 1996 and 20 April 1996. 